\title{
Review \\ Obstructive Sleep Apnea and Cognitive Decline: A Review of Potential Vulnerability and Protective Factors
}

\author{
Julie Legault ${ }^{1,2}$, Cynthia Thompson ${ }^{1}$, Marie-Ève Martineau-Dussault ${ }^{1,2}$, Claire André ${ }^{1,2}{ }^{\circledR}$, Andrée-Ann Baril ${ }^{3}{ }^{\circledR}$, \\ Guillermo Martinez Villar ${ }^{1,2}$, Julie Carrier ${ }^{1,2}$ a and Nadia Gosselin 1,2,* \\ 1 Center for Advanced Research in Sleep Medicine, Hôpital du Sacré-Coeur de Montréal, \\ Recherche CIUSSS NIM, Montreal, QC H4J 1C5, Canada; julie.legault@umontreal.ca (J.L.); \\ cynthia.thompson.cnmt1@ssss.gouv.qc.ca (C.T.); marie-eve.martineau-dussault@umontreal.ca (M.-È.M.-D.); \\ claire.andre@umontreal.ca (C.A.); guillermo.martinez.villar@umontreal.ca (G.M.V.); \\ julie.carrier.1@umontreal.ca (J.C.) \\ 2 Department of Psychology, Université de Montréal, Montreal, QC H3C 3J7, Canada \\ 3 Douglas Mental Health University Institute, McGill University, Montreal, QC H4H 1R3, Canada; \\ andree-ann.baril@umontreal.ca \\ * Correspondence: nadia.gosselin@umontreal.ca
}

\section{check for} updates

Citation: Legault, J.; Thompson, C.; Martineau-Dussault, M.-È.; André, C.; Baril, A.-A.; Martinez Villar, G.; Carrier, J.; Gosselin, N. Obstructive Sleep Apnea and Cognitive Decline: A Review of Potential Vulnerability and Protective Factors. Brain Sci. 2021, 11,706. https://doi.org/10.3390/ brainsci11060706

Academic Editors: Luigi De Gennaro and Maurizio Gorgoni

Received: 2 May 2021

Accepted: 25 May 2021

Published: 27 May 2021

Publisher's Note: MDPI stays neutral with regard to jurisdictional claims in published maps and institutional affiliations.

Copyright: (c) 2021 by the authors. Licensee MDPI, Basel, Switzerland. This article is an open access article distributed under the terms and conditions of the Creative Commons Attribution (CC BY) license (https:/ / creativecommons.org/licenses/by/ $4.0 /)$.

\begin{abstract}
Around 40\% of dementia risk is attributable to modifiable risk factors such as physical inactivity, hypertension, diabetes and obesity. Recently, sleep disorders, including obstructive sleep apnea (OSA), have also been considered among these factors. However, despite several epidemiological studies investigating the link between OSA and cognitive decline, there is still no consensus on whether OSA increases the risk of dementia or not. Part of the heterogeneity observed in previous studies might be related to some individual characteristics that modulate the association between OSA and cognitive decline. In this narrative review, we present these individual characteristics, namely, age, sex, menopause, obesity, diabetes mellitus, hypertension, cardiovascular diseases, smoking, excessive alcohol consumption, depression, air pollution, Apolipoprotein E $\varepsilon 4$ allele, physical activity, and cognitive reserve. To date, large cohort studies of OSA and cognitive decline tended to statistically control for the effects of these variables, but whether they interact with OSA to predict cognitive decline remains to be elucidated. Being able to better predict who is at risk of cognitive decline when they have OSA would improve clinical management and treatment decisions, particularly when patients present relatively mild OSA.
\end{abstract}

Keywords: aging; sleep; obstructive sleep apnea; cognitive decline; mild cognitive impairment; Alzheimer's disease; dementia; ApoE genotype; risk factors; comorbidities

\section{Introduction}

More and more people are living with dementia worldwide, with no curative treatment in sight. Alzheimer's disease (AD) is by far the most common form of dementia, representing $60-70 \%$ of all dementia cases [1], and is generally preceded by a predementia stage of mild cognitive impairment (MCI). Around $40 \%$ of worldwide dementia cases are thought to be attributable to potentially modifiable risk factors, including diabetes, hypertension, obesity, physical inactivity, depression, smoking, low educational attainment, hearing impairment, low social contact, excessive alcohol consumption, and air pollution [2]. In addition, there is a growing body of evidence supporting the role of sleep disorders in the development of MCI and dementia [3-5], among which obstructive sleep apnea (OSA) could represent a modifiable risk factor of particular interest [6-9]. Therapeutic interventions targeting these modifiable risk factors may have the potential to delay dementia onset and slow its progression. Therefore, it is essential to properly identify these modifiable risk factors, and to fully understand the mechanisms by which they may increase the risk of dementia. Moreover, it is also essential to better understand 
how modifiable risk and protective factors interact to increase or reduce a person's vulnerability to dementia. Better identifying individuals who could benefit from potential preventive therapies and those who should be included in clinical trials is a worldwide objective $[10,11]$.

In this narrative review, we aim to identify individual vulnerability and protective characteristics that could have an impact on the relationship between OSA and cognitive decline, specifically MCI and AD. After defining OSA, we will present the potential mechanisms underlying the link between OSA and cognitive decline, and synthesize epidemiological studies investigating this association. We will then discuss potential vulnerability and protective characteristics that may moderate the association between OSA and cognitive decline, namely, age, sex, menopause, obesity, diabetes mellitus, hypertension, cardiovascular diseases, smoking, excessive alcohol consumption, depression, air pollution, Apolipoprotein E \&4 (ApoE4) allele, physical activity, and cognitive reserve. Understanding the roles and mechanisms of both vulnerability and protective individual characteristics could shed light on the discrepancies observed between cohort studies and eventually help individualize therapeutical intervention to prevent cognitive decline in OSA patients.

\section{Definition and Prevalence of OSA}

OSA is a respiratory disorder characterized by repeated episodes of partial (hypopnea) and complete (apnea) obstructions of the upper airway during sleep [12,13]. These recurrent respiratory events lead to cortical arousal and sleep fragmentation, intermittent hypoxemia, and increased sympathetic activity, affecting sleep quality and daytime functioning [14]. OSA severity is typically assessed with the apnea-hypopnea index (AHI), which is the average number of apneas and hypopneas per hour of sleep. The severity of OSA is determined according to the following thresholds: mild (AHI $\geq 5$ and $<15$ ), moderate $(\mathrm{AHI} \geq 15$ and $<30)$ or severe $(\mathrm{AHI} \geq 30)$ [15]. According to a systematic review in the adult population, $9-38 \%$ of individuals present with mild OSA and $6-17 \%$ present with moderate to severe OSA [16]. In the elderly, these estimations reach up to $84 \%$ for mild OSA and 36\% for moderate to severe OSA [16]. Even more worrying, one study observed that $56 \%$ of adults aged 65 and older were at high risk of OSA, while only $8 \%$ of them had been tested for OSA and diagnosed [17]. Thus, many older adults remain undiagnosed, and therefore not treated. Furthermore, when people do get diagnosed, only about $41 \%$ remain adherent to their continuous positive airway pressure (CPAP) treatment after one year [18]. This low CPAP adherence is alarming, especially considering that this treatment could delay cognitive decline in individuals with OSA [9].

\section{Potential Mechanisms Linking OSA and Cognitive Decline in Older Adults}

It is well established that OSA causes sleep fragmentation and intermittent hypoxemia. More specifically, repeated micro-arousals alter both sleep macroarchitecture (time spent in stage N3 and rapid-eye movement (REM) sleep) [19] and microstructure (slow-wave and spindle characteristics) [20-23]. Considering the critical roles of sleep continuity, slowwave sleep, REM sleep, and sleep spindles in neurogenesis, brain plasticity, alertness, and memory formation and consolidation [24,25], chronic sleep changes caused by OSA could negatively affect cognitive health $[6,26,27]$. REM-dependent OSA could be particularly harmful to the brain, with respiratory events occurring during this sleep stage being associated with reduced daytime regional cerebral blood flow, even in mild OSA [28]. Indeed, muscle atonia during REM sleep can increase the occurrence and the hypoxic levels of respiratory obstructive events, and thus, some individuals present respiratory events mostly in this sleep stage. Further, REM-dependent OSA is more strongly associated with excessive daytime sleepiness than NREM-OSA [29], which is in turn related to cognitive impairment [30].

Moreover, both sleep fragmentation and intermittent hypoxia interfere with brain structure and function, increasing their vulnerability to neurodegenerative diseases. In- 
deed, it has been suggested that a biphasic pattern of neuroimaging findings could be in play in OSA [31], with acute transitory or compensatory responses (i.e., gray matter hypertrophy, restricted white matter diffusivities) followed by evidence of cellular damage (i.e., gray matter atrophy, higher white matter hyperintensity burden, lower white matter fractional anisotropy, higher water diffusivities). In addition, OSA has been recently associated with increased amyloid and tau burden [21,32-43], two proteins involved in AD pathophysiology. Several mechanisms likely underlie these neuroimaging or pathological findings and include inflammation, oxidative stress, metabolic disturbances, cerebral edema and endothelial dysfunction [27]. Indeed, inflammation is involved in neurodegenerative processes, notably by triggering a positive feedback loop that increases amyloid beta production and oxidative stress, facilitating amyloid and tau pathology [26,44].

\section{Cohort Studies Investigating the Association between OSA and Cognitive Decline in Older Adults}

\subsection{Cross-Sectional Studies}

The majority of large cross-sectional cohort studies investigating the association between OSA and cognitive impairment in middle-aged and older adults have used objective sleep measures, i.e., polysomnography or portable devices, to evaluate OSA [45-52], and one study used a questionnaire to screen for OSA [53]. While some studies have investigated cognitive performance using comprehensive neuropsychological batteries [51,53,54], others used a limited number of neuropsychological tests targeting specific cognitive functions or global functioning $[45,46,49,52]$. In studies showing that OSA is associated with poorer cognitive functioning, associations were found for long-term verbal memory [47], working memory [47] and global cognition [52]. The OSA severity markers or OSA-related symptoms associated with cognition were highly heterogeneous across studies, including snoring [53], self-reported apneas [53], hypoxemia [45,54] and AHI [50,51]. Other studies have not found a significant association between any OSA severity marker and cognition $[46,48,49]$.

Despite the heterogenous results emerging from cross-sectional studies, associations between OSA and cognitive functioning seem better established in the domains of attention, memory, and processing speed, while less evidence supports an association between OSA and working memory, executive functions, language and visual abilities in middle-aged and older adults. Interestingly, in younger adults, the most affected cognitive domains in OSA are attention, episodic memory, working memory, and executive functions [14]. This suggests that while some cognitive domains appear to be affected by OSA regardless of the age (namely, memory and attention), other cognitive domains seem less impacted by OSA with increasing age, such as executive function and working memory.

\subsection{Longitudinal Studies}

Longitudinal cohort studies have the advantage of quantifying cognitive decline over time. They used self-reported diagnoses (e.g., [9,55]) or in-home polysomnography or portable devices (e.g., [7,56-59]) to identify OSA cases. Furthermore, the majority of these studies used global cognitive measures or screening tools, such as the Mini-Mental State examination (MMSE; e.g., [7,59]), while a comprehensive neuropsychological battery was used in one study [58].

Among the main longitudinal cohort studies, the Study of Osteoporotic Fractures included 298 82-year-old women and found that $45 \%$ of women with OSA developed MCI or dementia at five-year follow-up, compared to $31 \%$ of women without OSA [59]. However, neither of the two neuropsychological tests used to assess global cognition and executive functions could identify impairment of specific cognitive functions related to OSA. This result was also obtained in the Atherosclerosis Risk in Communities Study that included men and women aged 45-64 years and failed to show an association between OSA and specific cognitive tests at 15-year follow-up [56], while highlighting an increased risk of dementia in individuals with severe OSA [57]. In the Osteoporotic Fractures in 
Men Sleep Study, including men aged 65 and older, another team showed a negative relationship between baseline nocturnal hypoxemia and global cognitive functioning after three years, while executive functions were not associated with OSA [7]. On the other hand, the Proof-SYNAPSE study used a wide selection of neuropsychological tests in men and women aged 65 years and showed only a slight decline in attention related to OSA after eight years, without any change in executive functions and memory [58].

In summary, studies using measures of global cognition and clinical diagnosis of cognitive impairment or dementia were more susceptible to highlight cognitive decline associated with OSA over time than those using comprehensive neuropsychological batteries [56-58]. This suggests that longitudinal studies are more susceptible to identify major OSA-related cognitive decline over time, but not milder cognitive decline in specific domains.

\subsection{Meta-Analyses, Meta-Reviews and Systematic Reviews}

Most meta-analyses and systematic reviews concluded that a significant association between OSA and cognition exists [8,60-62] and that OSA increases the risk of AD [63-65]. Interestingly, these meta-analyses and systematic reviews highlighted the fact that small cohorts and controlled case studies from sleep clinics have shown effects of OSA on cognition $[66,67]$, while most studies of large community-based cohort studies failed to show significant associations $[45,56]$. Another systematic review concluded that the link between OSA and cognition is weak [68], possibly due to the age range used (50 years and over, while others included studies of participants aged 30 years and over $[8,60,62])$. Similarly, another systematic review showed a significant association between OSA and cognition only in adults younger than 60 years [60]. In addition to age, the variability in the strength of the association could also be due to the study types and designs, the recruitment methods and/or that only more severe OSA cases are associated with cognitive dysfunction.

\section{Vulnerability Risk Factors}

Not all adults with OSA are at high risk of developing MCI or dementia. Individual characteristics are likely to add to or interact with OSA severity to explain the increased risk of cognitive decline when present. Some variables are difficult to quantify, such as OSA disease duration, and will not be discussed here. Rather, we will focus on factors that should be included as moderating factors in future studies investigating the risk of cognitive decline in OSA. Of note, some studies considered potential moderating variables as confounders, such as $A p o E 4$, sex and age. These are discussed in detail in the following subsections. Table 1 summarizes these potentially moderating factors.

\subsection{Age}

Age is a well-established risk factor for both OSA [17,82] and dementia [83]. The increased prevalence of OSA with age could be explained in part by indirect factors that are associated with dementia risk (e.g., increasing body mass index, menopause, increasing prevalence of health comorbidities), but also by the marked decrease in tongue and palate muscle activity during sleep in older adults $[84,85]$. We could therefore hypothesize that older age potentiates the negative effects of OSA on brain health, but the opposite seems to be observed. In fact, a recent systematic review that included 68 studies showed that young and middle-aged adults (30 to 60 years old) suffering from OSA had impairments in attention, executive functions and memory, while apneic adults aged 60 and over had cognitive functioning comparable to non-apneic people of the same age [60]. It is possible that other conditions occurring mainly with advancing age, such as cardiovascular diseases, hypertension and neurodegenerative diseases, could significantly influence cognitive functioning in the elderly, and therefore hide or blur the association between apnea and cognition. This could explain the weaker association between OSA and cognition; however, this hypothesis remains to be tested. 
Table 1. Individual characteristics that could interact with OSA severity to predict risk of cognitive decline.

\begin{tabular}{|c|c|c|c|}
\hline Evidence Availability & $\begin{array}{c}\text { Individual } \\
\text { Characteristics }\end{array}$ & $\begin{array}{l}\text { Individuals with OSA Potentially at } \\
\text { Increased Risk of Cognitive Decline }\end{array}$ & $\begin{array}{l}\text { Studies Supporting } \\
\text { the Potential Role }\end{array}$ \\
\hline \multirow{2}{*}{$\begin{array}{l}\text { A few studies have } \\
\text { tested these variables }\end{array}$} & Sex & Women & {$[52,69-71]$} \\
\hline & ApoE4 & ApoE4 carriers & {$[47,52,72,73]$} \\
\hline \multirow{3}{*}{$\begin{array}{c}\text { Almost no studies } \\
\text { have tested } \\
\text { these variables }\end{array}$} & Menopause & Postmenopausal women & [74] \\
\hline & Smoking & Smokers & [75] \\
\hline & Cognitive reserve & Individuals with a low cognitive reserve & [76] \\
\hline \multirow{9}{*}{$\begin{array}{l}\text { Heterogeneous results } \\
\quad \text { or not tested }\end{array}$} & Age & Young and middle-aged adults & {$[60]$} \\
\hline & Obesity & Obese individuals & {$[26,77]$} \\
\hline & Diabetes mellitus & Diabetic individuals & No evidence found \\
\hline & Hypertension & Individuals with hypertension & {$[78,79]$} \\
\hline & Cardiovascular diseases & Individuals with cardiovascular diseases & No evidence found \\
\hline & $\begin{array}{l}\text { Excessive alcohol } \\
\text { consumption }\end{array}$ & $\begin{array}{l}\text { Individuals having moderate to high } \\
\text { alcohol consumption }\end{array}$ & No evidence found \\
\hline & Depression & Individual with depression & [80] \\
\hline & Physical activity & Inactive individuals & [81] \\
\hline & Air pollution & Individuals exposed to high levels of air pollution & No evidence found \\
\hline
\end{tabular}

\subsection{Sex and Menopause}

The prevalence of dementia is higher in women by $19-29 \%$ in many parts of the world, including Europe, Latin America, Australia, and areas outside of the Pacific region of Asia [86], and women represent approximately two-thirds of AD dementia cases in the United States [87]. In addition to women's longer life expectancies as compared to men's, this disparity could be due to the different effects of some risk factors in men and women, with some being more common (e.g., lower access to education) and having a stronger impact in women than in men (e.g., ApoE4 genotype), and others being specific to women (e.g., menopause) [87].

With respect to OSA, men, as compared to women, tend to accumulate more fatty tissue in the upper body, especially in the pharynx, which promotes airway collapse and blockage leading to OSA [12]. Accordingly, epidemiological studies using polysomnography, questionnaires or self-reported OSA diagnoses found a prevalence ranging from $13 \%$ to $31 \%$ in men and $4 \%$ to $21 \%$ in women [88-93]. Moreover, men and women with OSA seem to experience different symptoms. Men report snoring, shortness of breath and apnea observed by the bed partner, while women report non-specific symptoms such as headaches, fatigue, depression, anxiety and insomnia [94,95], suggesting a sex-specific impact of OSA on diurnal functioning. Of note, these sex differences might reflect an assessment bias. In fact, since initial research was mainly conducted in men, their symptoms appear to be more typical, while women's symptoms might be as frequent, but have received less attention. Furthermore, women might experience similar symptoms as men, but these symptoms might be less frequently reported by their bed partners.

Few studies have examined sex differences in the association between OSA and cognition. Among them, two Taiwanese studies found an interaction effect between sex and sleep disturbances on cognition [71,96]. Chiu et al. [96] showed that men reporting difficulty breathing during sleep, habitual snoring, and prolonged sleep duration $(>8.5 \mathrm{~h})$ were at higher risk of cognitive impairment, whereas in women, only prolonged sleep duration was associated with cognitive impairment. However, Chang et al. [71] showed that women with OSA, but not men, were more likely to develop dementia. Similarly, the Hispanic Community Health Study showed no association between OSA and cognition in men, while a high $\mathrm{AHI}$ in women was associated with a marked decrease in cognitive 
performance in all three cognitive domains assessed (executive function, memory and information processing speed) [69]. Age stratified analyses indicated that this sex effect was specific to the 45-54 age group, which corresponds to the age of perimenopause in most women. In older women (65-74 years), only an association between OSA and information processing speed was observed. Interestingly, cross-sectional studies of cohorts including only women showed significant associations between OSA and poorer cognition [52,70], while cohorts including only men showed no such association [45,49]. Neuroimaging studies from one group included between 10 and 16 women with OSA and highlighted OSA and sex interactions, where only women showed white matter alterations [97], cortical thinning [98] and unilateral volume changes in the hippocampus [99].

Physiological mechanisms that could explain women's vulnerability are still not clear, but the inflammatory response to OSA is among those suspected. An interesting study of apneic adults without known comorbidities showed an increase in inflammatory biomarkers and cardiovascular risk markers (e.g., C-reactive protein, fibrinogen and elevated erythrocyte sedimentation rate) particularly in women, even though apneic men showed higher levels of uric acid, a marker of hypoxia [100]. With equivalent AHI, women have higher levels of fibrinogen and C-reactive protein compared to men [101].

Menopause is another factor that could explain women's vulnerability to OSA. Importantly, menopause is accompanied by decreased metabolic activity and increased amyloid burden, characteristics of an AD endophenotype [102]. In fact, a three-year longitudinal study observed postmenopausal women and showed a higher rate of amyloid deposition compared to pre-menopausal women and men, and a higher rate of hippocampal volume loss compared to pre- and perimenopausal women and men [103]. AD pathology appears years to decades prior to clinically detectable symptoms, corresponding to the age of perimenopause in most women [102]. Menopause transition could thus increase the risk of $\mathrm{AD}$ in women.

Menopause is characterized by estrogen and progesterone depletion, which triggers an adipose tissue distribution change, making this distribution similar to what is observed in men [13]. Postmenopausal women have more adipose accumulation in the upper body and increased body mass index (BMI), neck circumference, and waist-to-hip ratio, all increasing their risk of OSA [104]. Indeed, postmenopausal women not using hormone replacement therapy are three to four times more likely than non-menopausal women to suffer from OSA, suggesting a protective role for estrogen and progesterone against OSA [13,105].

Postmenopausal women at high risk of OSA, as assessed by the Berlin Questionnaire [106], reported more subjective cognitive impairment than those at low risk of OSA [74]. An interesting review about ovarian hormones, sleep, and cognition suggests that the loss of ovarian hormones following menopause could increase the development of sleep disorders, and thus could precipitate cognitive decline and dementia in women [107]. More precisely, increases in sleep disorders could enhance inflammation, leading to neurodegeneration and cognitive decline. Thus, menopause could accelerate OSA-related cognitive decline. Although limited data are available, a recent meta-analysis showed that hormone replacement therapy improves cognitive function in women with AD [108]. Since hormone replacement therapy improves sleep in some, but not all studies [107], its potential to reduce OSA-related vulnerability to cognitive decline needs to be investigated.

\subsection{Obesity}

Results from a 36-year longitudinal study showed that middle-aged adults with a combination of obesity and high abdominal circumference have a 3.6-fold increase in dementia risk, even after controlling for diabetes and other vascular comorbidities [109]. This increased risk can be explained by the fact that adipocytes secrete pro-inflammatory cytokines that alter synaptic and neuronal plasticity, which in turn contributes to neurodegenerative processes [110]. Furthermore, obesity-related inflammation leads to oxidative stress, which also plays a role in neurodegenerative processes [111]. 
The risk of OSA increases progressively with BMI and is even more strongly associated with neck circumference [112]. Obesity is the strongest risk factor for OSA and its relationship with OSA might be bidirectional [113]. While obesity is linked to several co-morbidities exacerbated by OSA, such as myocardial infarction, congestive heart failure, stroke, type 2 diabetes and hypertension, OSA is thought to increase the risk of obesity due to the physical inactivity associated with daytime sleepiness [113].

Considering obesity's possible contribution to neurodegenerative processes and its strong link to OSA, Polsek et al. [26] suggested that co-morbid obesity could promote AD progression in individuals with OSA. Yet, most studies investigating the link between OSA and cognitive decline have statistically controlled for obesity but have not stratified their analyses according to obesity. Interestingly, one recent study found that obese OSA patients have reduced performance in working memory and psychomotor vigilance compared to non-obese OSA patients [77]. More studies are therefore needed to verify if overweight or obese adults are particularly vulnerable to cognitive alterations linked to OSA.

\subsection{Diabetes Mellitus}

A pooled meta-analysis of 2.3 million individuals with type 2 diabetes showed that diabetes is associated with a 1.6-fold increase in dementia risk [114]. In addition to a possible increase in amyloid and tau burden in diabetic patients [115,116], non-AD mechanisms could also link type 2 diabetes to neurodegeneration, as a result of insulin resistance disturbing cerebral insulin pathways, vascular endothelial dysfunction leading to hypoxic neuronal injury and inflammation disrupting the blood-brain barrier [117].

Up to $30 \%$ of patients with OSA suffer from type 2 diabetes [118], and up to $86 \%$ of obese patients with type 2 diabetes suffer from OSA [119]. The link between OSA and diabetes is believed to be bidirectional but has not yet been fully elucidated. On the one hand, the autonomic dysfunction characteristic of diabetes could lead to respiratory instabilities, increasing the risk of OSA [120]. On the other hand, intermittent hypoxemia, sleep fragmentation and reduced time spent in N3 and REM sleep in OSA may increase the risk of developing alterations in glucose metabolism such as insulin resistance, glucose intolerance and type 2 diabetes [120-123].

Regarding the interaction between diabetes and OSA, a study of adults (mean age = 55 years) with prediabetes or type 2 diabetes found no association between OSA and cognitive performance [124]. It is important to mention that most participants (43\%) had only mild OSA in that study. Thus, more studies are needed to verify if cognitive impairment and decline are particularly important in diabetic individuals with mild, moderate or severe OSA.

\subsection{Hypertension}

Results from the Framingham Offspring cohort study showed that midlife systolic hypertension and the persistence of systolic hypertension into later life were associated with a 1.6 to 2 -fold increase in dementia risk at 18-year follow-up [125]. Various pathways could link hypertension to dementia, including small vessel disease, large artery atherosclerosis, and hypertension-related cardiac dysfunction, which predispose to cerebral hypoperfusion [125].

An estimated $50 \%$ of patients with hypertension present with OSA [126]. Conversely, individuals with OSA have an extra 1.8-fold risk of resistant hypertension compared to those without OSA [127]. The link between OSA and hypertension could be explained by anatomical changes resulting from hypoxia. In fact, intermittent hypoxia triggers an intense cardiovascular response, leading to sympathetic overactivity, which in turn contributes to hypertension [128]. It is therefore possible that intermittent hypoxemia and sleep fragmentation accentuate the effects of hypertension on cognitive decline, while hypertension may in turn potentiate the effects of OSA on the risk of dementia by increasing oxidative stress and inflammatory response [78]. Moreover, a study of men and women aged 60 years and older showed working memory impairment related to OSA and hypertension [79]. 


\subsection{Cardiovascular Diseases}

Dementia and cardiovascular diseases share common risk factors that could lead to cognitive decline, such as diabetes mellitus, smoking, and hypertension [129]. Moreover, studies have also linked dementia to specific cardiovascular diseases, such as coronary heart disease, atrial fibrillation and heart failure [129]. While it is not yet established if cardiovascular diseases per se increase the risk of dementia or if it is due to shared risk factors, cardiovascular diseases could contribute directly to cognitive decline through cerebral hypoperfusion, hypoxia, embolisms, and infarcts [129]. Moreover, one study showed that genetic predisposition to coronary artery disease increases dementia risk three years after a cardiovascular disease diagnosis [130].

It is difficult to isolate the independent role that cardiovascular diseases may play in OSA because of the concomitant presence of other cardiovascular risk factors such as obesity and glucose intolerance [131]. However, the prevalence of OSA is estimated to be two to three times higher in people with cardiovascular diseases [132], and up to 50\% of apneic patients show cardiac and metabolic abnormalities [131]. Fragmented sleep and recurrent cycles of decreased oxygen levels and reoxygenation associated with OSA lead to oxidative stress and inflammation, which damage blood vessel walls and increase hypertension $[133,134]$. Considering the cascade of deleterious consequences produced by both OSA and cardiovascular diseases, it is likely that treating OSA could help mitigate their negative impacts on brain health.

\subsection{Smoking}

It is highly recognized that smoking increases the risk of cognitive decline and dementia [2,135]. A multi-ethnic cohort study including adults aged 50-60 years indicates that smoking more than two packs of cigarettes daily doubles the risk of dementia at 23-year follow-up [136]. In addition, a Chinese study conducted with current, past and nonsmokers aged 20-60 years who reported snoring or daytime drowsiness showed that the coexistence of OSA and chronic smoking results in more pronounced cognitive impairment than smoking alone [75]. Specifically, inhaling cigarette smoke increases oxidative stress and systemic inflammation, phenomena also observed in OSA [75]. Thus, the concomitant presence of smoking and OSA could precipitate cognitive decline.

\subsection{Excessive Alcohol Consumption}

A scoping review of 28 systematic reviews revealed that excessive alcohol consumption is linked to an increased dementia risk, while low to moderate drinking is associated with a decreased risk [137]. Alcohol could lead to brain damage directly, through its neurotoxic effect on brain structure and function [137]. In fact, chronic alcohol abuse could lead to loss of white matter, with astrocytes, oligodendrocytes, and synaptic terminals being particularly vulnerable to the toxic effects of alcohol [138]. Moreover, heavy alcohol consumption can cause high blood pressure, ischemic heart disease, cardiomyopathy, atrial fibrillation, and strokes, which are in turn associated with increased risk of vascular dementia $[137,139]$. Low to moderate alcohol consumption is associated with lower odds for dementia than abstainers; while this link is not yet well understood, the inclusion of former drinkers who might have already suffered from alcohol-related consequences in the group of abstainers could explain part of the results [140].

Due to its relaxing properties, alcohol increases upper airway collapsibility and could thus represent a risk factor for the occurrence of apneas when it is ingested before bedtime [141-143]. Results from systematic reviews and meta-analysis revealed that alcohol consumption is associated with a $25 \%$ increased risk of OSA [143], an increase in AHI of 2.33 to 3.98 events per hour, and a $0.60 \%$ to $2.72 \%$ decrease in lowest oxygen saturation $[142,144]$. Furthermore, results from the Wisconsin Sleep Cohort Study showed that alcohol's negative impact on OSA may not be restricted to its consumption near bedtime, but to its habitual consumption [141]. In fact, for each increase of one self-reported drink per day, men had 25\% greater odds of OSA, while women's alcohol consumption was not 
associated with OSA [141]. However, no study has investigated the presence of cognitive dysfunction in OSA adults having moderate to high alcohol consumption. Thus, alcohol could represent a modifiable risk factor for dementia when consumed in excess and could also predispose to OSA even in a lower dosage.

\subsection{Depression}

Cohort studies and meta-analyses suggest that a history of depression is associated with an increased dementia risk, with depressive symptoms independently associated with cognitive decline [2,145]. However, it is not well established whether depression increases the risk of dementia or is an early marker of brain changes associated with dementia [2,135].

A systematic review and meta-analysis indicates that OSA is linked to depression, with longitudinal studies being more susceptible to highlight cognitive decline associated with OSA than cross-sectional studies [146]. In fact, two longitudinal studies suggested that OSA is an independent risk factor for depression, with participants with OSA being about twice as likely to be depressed as those without OSA [147,148]. According to a model developed by Kerner and Roose [80], cerebral hypoperfusion, endothelial dysfunction and neuroinflammation due to OSA could initiate or amplify the development of cerebral small vessel disease and blood-brain barrier dysfunction, resulting in white matter lesions, gray matter loss, white matter fiber tract abnormalities, neuronal damage, synaptic plasticity and neurodegenerative processes, in turn leading to depressive symptoms and cognitive impairment [80]. One study found that depressive symptoms observed in OSA patients were associated with accentuated excessive daytime sleepiness [149]. Whether depression in OSA patients is a daytime consequence of OSA, an early marker of neurodegeneration, or a risk factor that interacts with OSA to hasten cognitive decline is a highly relevant clinical question.

\subsection{Air Pollution}

Air pollution is a recognized risk factor for dementia [2,150,151]. A systematic review of longitudinal studies suggested that exposure to particulate matter, nitrogen dioxide and carbon monoxide increases dementia risk [151]. It has been hypothesized that the mechanisms underlying the effects of air pollution on brain health could include inflammation, microglial activation, reactive oxygen species, and the production and deposition of amyloid-beta peptides [150].

Although it is well known that air pollution has deleterious effects on respiratory health, its relationship with OSA remains unclear [152]. A recent systematic review including five cross-sectional studies of adults objectively assessed for OSA suggested a relationship between air pollution exposure and increased risk of OSA, with variability attributed to seasons, temperatures and geographic locations [152].

Furthermore, air pollution and OSA share common potential pathways to health conditions and cognitive decline such as hypertension, insulin resistance, oxidative stress, inflammation and endothelial dysfunction [151]. Laratta et al. [153] suggested an interaction of OSA and air pollution on systemic inflammation. In fact, this team observed increased levels of inflammation with high particulate matter exposure in individuals with suspected OSA, and with black carbon exposure in patients with moderate to severe OSA [153]. Considering the potential deleterious effects of both inflammation and health conditions on the brain, it is likely that OSA and exposure to air pollution have a joint negative effect on cognitive health. Moreover, air pollution and OSA could increase dementia risk through an indirect pathway related to metabolic dysfunctions such as diabetes [154], hyperglycemia and low high-density lipoprotein cholesterol [155]. Future studies should verify if exposure to air pollution makes patients particularly vulnerable to cognitive alterations linked to OSA. 


\subsection{ApoE4}

ApoE is a protein involved in cholesterol transport, growth and repair of the nervous system during development or after injury, synaptic and dendritic remodeling, and the scavenging of amyloid [156-158]. Carriers of the ApoE4 allele have decreased expression of the ApoE protein, and thus, its beneficial role in the central nervous system is reduced.

The ApoE4 allele remains, to this day, the strongest genetic risk factor for sporadic AD [156,159]. Most studies have shown an association between ApoE4 allele carrier status and poor performance in various cognitive domains in elderly people without dementia [160-162]. Even with the increased prevalence of OSA in older individuals, these studies did not take into account the presence or absence of OSA in their analyses. However, the presence of ApoE4 alone is not sufficient to cause cognitive decline and is thought to be a susceptibility factor that interacts with other genetic and environmental influences to increase the risk of cognitive decline [162,163]; one of these factors could be OSA.

While one study showed that $A p o E 4$ was associated with an increased risk of moderate to severe OSA and higher AHI [164], others did not show this link [165-167]. A few studies have shown that in apneic patients aged 30 or over, the presence of the ApoE4 allele is associated with more cognitive impairment as compared to non-carriers $[47,52,72,73]$. These results could be explained by the vulnerability of ApoE4 carriers to central nervous system injuries of various origins, such as the oxidative stress associated with OSA [72,73]. Whether cognitive impairment in ApoE4 carriers with OSA progresses to dementia is a question that must be investigated.

\section{Protective Factors}

\subsection{Physical Activity}

Physical inactivity is the most significant modifiable risk factor for AD in the United States, Europe and England, where approximately one-third of the adult population is physically inactive (i.e., less than $20 \mathrm{~min}$ of vigorous activity during three or more days or less than $30 \mathrm{~min}$ of moderate activity during five or more days per week) [168]. Results from randomized controlled trials in healthy inactive older adults show that low-intensity exercise programs improve cognitive functioning and decrease the risk of cognitive decline [135]. Physical activity promotes brain plasticity and neurogenesis as well as vascular health by reducing blood pressure, lipids, obesity, and markers of inflammation [169]. In addition, physical activity is associated with lower levels of $\mathrm{AD}$ pathology such as tau and beta-amyloid [170].

A systematic review of physical activity and OSA suggests that apneic patients often display low levels of physical activity, possibly due to the fatigue and daytime sleepiness characteristics of OSA [81]. Conversely, exercise training programs of at least a three-week duration are associated with a decrease in $\mathrm{AHI}$ and symptoms of drowsiness despite no change in BMI [81]. This decrease in OSA symptomatology may be due to increased upper airway dilator strength and fatigue resistance, decreased nasal resistance, and increased respiratory stability during deep sleep [171]. Physical activity could therefore improve OSA symptoms and cognitive performance, and possibly delay OSA-related cognitive impairment, but this needs to be tested.

\subsection{Cognitive Reserve}

The level of education, intelligence and main occupation are markers of the cognitive reserve, which makes it possible to withstand a deterioration of cerebral structures and to preserve cognitive and behavioral functions at an optimal level when a neurodegenerative process sets in [172]. Worldwide, low levels of education are believed to be the most important modifiable risk factor for AD [168].

With respect to OSA, higher intelligence is thought to have a protective effect against OSA-related cognitive decline, possibly due to the associated cognitive reserve, and may compensate for the hypoxic brain damage or daytime sleepiness associated with OSA [76]. In fact, one study showed similar levels of attention in highly intelligent participants with 
and without OSA, while in those with normal intelligence, apneic patients had reduced attention compared to the control group [76]. Since cognitive reserve is a well-established protective factor of dementia, future studies will need to determine whether cognitive reserve can delay, or even prevent, cognitive decline in apneic patients.

\section{Clinical Impact and Future Directions}

Clinicians often face a dilemma as to whether they should treat patients with mild OSA or those with low diurnal symptoms. When they prescribe OSA treatment, patients may refuse it or may fail to use it on an on-going basis. With the recent findings on OSA and the risk of cognitive decline, clinicians and patients should now take into account the risk of developing dementia if OSA remains untreated. Identifying vulnerability and protective characteristics in OSA and their impact on cognitive decline has the potential to guide clinicians in treatment decisions, for example, through the use of decision trees or software/web applications based on machine learning and available for clinicians. Patients presenting with OSA and multiple vulnerability factors for cognitive decline could thus be offered treatment even if they only have mild OSA. To improve the management of OSA in this at-risk population, systematic screening for OSA could be implemented in memory clinics and cardiology/cardiovascular hospital units.

Furthermore, studies investigating the link between OSA and cognitive decline often do not characterize participants with respect to underlying pathology. Since AD pathology is present during a long silent phase, it is possibly present in some participants and left undetected by cognitive screening. Since the influence of risk and protective factors possibly differs according to the presence or absence of AD pathology, future studies should quantify participants' AD pathology. Finally, patients with multiple sleep disorders (i.e., those with OSA combined with insomnia, REM sleep behavior disorder, circadian misalignment) may be at higher risk of cognitive decline and dementia. The effects of having multiple sleep disorders should be investigated in future studies, rather than excluding patients based on comorbid sleep disorders.

Author Contributions: Writing—original draft preparation, J.L.; N.G.; writing—review and editing, C.T.; M.-È.M.-D.; C.A.; A.-A.B.; G.M.V.; J.C.; funding acquisition, J.C. and N.G. All authors have read and agreed to the published version of the manuscript.

Funding: N.G. holds a Canada Research Chair in Sleep Disorders and Brain Health and a Foundation grant from the Canadian Institutes of Health Research (CIHR, FDN154291). J.L. receives a Fonds de Recherche Santé-Québec (FRQS) scholarship. M.-È.M.-D. receives a CIHR scholarship. A.-A.B. receives CIHR, FRQS, and Banting fellowships. J.C. is supported by CIHR (PJT-153259) and the Canadian Sleep and Circadian Network.

Conflicts of Interest: The authors declare no conflict of interest.

\section{References}

1. Alzheimer's Association. 2016 Alzheimer's disease facts and figures. Alzheimer Dement. 2016, 12, 459-509. [CrossRef] [PubMed]

2. Livingston, G.; Huntley, J.; Sommerlad, A.; Ames, D.; Ballard, C.; Banerjee, S.; Brayne, C.; Burns, A.; Cohen-Mansfield, J.; Cooper, C.; et al. Dementia prevention, intervention, and care: 2020 report of the Lancet Commission. Lancet 2020, 396, 413-446. [CrossRef]

3. Bubu, O.M.; Brannick, M.; Mortimer, J.; Umasabor-Bubu, O.; Sebastião, Y.V.; Wen, Y.; Schwartz, S.; Borenstein, A.R.; Wu, Y.; Morgan, D.; et al. Sleep, Cognitive impairment, and Alzheimer's disease: A Systematic Review and Meta-Analysis. Sleep 2017, 40, 1-18. [CrossRef] [PubMed]

4. Yaffe, K.; Falvey, C.M.; Hoang, T. Connections between sleep and cognition in older adults. Lancet Neurol. 2014, 13, 1017-1028. [CrossRef]

5. Diem, S.J.; Blackwell, T.L.; Stone, K.L.; Yaffe, K.; Tranah, G.; Cauley, J.A.; Ancoli-Israel, S.; Redline, S.; Spira, A.P.; Hillier, T.A.; et al. Measures of Sleep-Wake Patterns and Risk of Mild Cognitive Impairment or Dementia in Older Women. Am. J. Geriatr. Psychiatry 2016, 24, 248-258. [CrossRef] [PubMed]

6. Gosselin, N.; Baril, A.-A.; Osorio, R.S.; Kaminska, M.; Carrier, J. Obstructive Sleep Apnea and the Risk of Cognitive Decline in Older Adults. Am. J. Respir. Crit. Care Med. 2019, 199, 142-148. [CrossRef] [PubMed] 
7. Blackwell, T.; Yaffe, K.; Laffan, A.; Redline, S.; Ancoli-Israel, S.; Ensrud, K.E.; Song, Y.; Stone, K.L. Associations Between Sleep-Disordered Breathing, Nocturnal Hypoxemia, and Subsequent Cognitive Decline in Older Community-Dwelling Men: The Osteoporotic Fractures in Men Sleep Study. J. Am. Geriatr. Soc. 2015, 63, 453-461. [CrossRef]

8. Leng, Y.; McEvoy, C.T.; Allen, I.E.; Yaffe, K. Association of sleep-disordered breathing with cognitive function and risk of cognitive impairment: A systematic review and meta-analysis. J. Am. Med. Assoc. Neurol. 2017, 74, 1237-1245. [CrossRef] [PubMed]

9. Osorio, R.S.; Gumb, T.; Pirraglia, E.; Varga, A.W.; Lu, S.E.; Lim, J.; Wohlleber, M.E.; Ducca, E.L.; Koushyk, V.; Glodzik, L.; et al. Sleep-Disordered Breathing Advances Cognitive Decline in the Elderly. Neurology 2015, 84, 1964-1971. [CrossRef]

10. Hing Tang, E.Y.; Robinson, L.; Maree Stephan, B.C. Dementia risk assessment tools: An update. Neurodegener. Dis. Manag. 2017, 7, 345-347. [CrossRef] [PubMed]

11. Lindley, R.I.; Waite, L.; Cullen, J. Dementia treatment: The need for a paradigm shift. Australas. J. Ageing 2019, 38, 149-150. [CrossRef]

12. Kryger, M.H.; Roth, T.; Dement, W.C. Principles and Practice of Sleep Medicine, 5th ed.; Elsevier Saunders: Philadelphia, PA, USA, 2011.

13. Young, T.; Peppard, P.E.; Gottlieb, D.J. Epidemiology of Obstructive Sleep Apnea: A Population Health Perspective. Am. J. Respir. Crit. Care Med. 2002, 165, 1217-1239. [CrossRef] [PubMed]

14. Gagnon, K.; Baril, A.A.; Gagnon, J.F.; Fortin, M.; Décary, A.; Lafond, C.; Desautels, A.; Montplaisir, J.; Gosselin, N. Cognitive impairment in obstructive sleep apnea. Pathol. Biol. 2014, 62, 233-240. [CrossRef] [PubMed]

15. Berry, R.B.; Budhiraja, R.; Gottlieb, D.J.; Gozal, D.; Iber, C.; Kapur, V.K.; Marcus, C.L.; Mehra, R.; Parthasarathy, S.; Quan, S.F.; et al. Rules for Scoring Respiratory Events in Sleep: Update of the 2007 AASM Manual for the Scoring of Sleep and Associated Events. Deliberations of the Sleep Apnea Definitions Task Force of the American Academy of Sleep Medicine. J. Clin. Sleep Med. 2012, 8, 597-619. [CrossRef]

16. Senaratna, C.V.; Perret, J.L.; Lodge, C.J.; Lowe, A.J.; Campbell, B.E.; Matheson, M.C.; Hamilton, G.S.; Dharmage, S.C. Prevalence of Obstructive Sleep Apnea in the General Population: A Systematic Review. Sleep Med. Rev. 2017, 34, 70-81. [CrossRef] [PubMed]

17. Braley, T.J.; Dunietz, G.L.; Chervin, R.D.; Lisabeth, L.D.; Skolarus, L.E.; Burke, J.F. Recognition and diagnosis of obstructive sleep apnea in older Americans. J. Am. Geriatr. Soc. 2018, 66, 1296-1302. [CrossRef] [PubMed]

18. Lee, C.H.K.; Leow, L.C.; Song, P.R.; Li, H.H.; Ong, T.H. Acceptance and Adherence to Continuous Positive Airway Pressure Therapy in Patients with Obstructive Sleep Apnea (OSA) in a Southeast Asian Privately Funded Healthcare System. Sleep Sci. 2017, 10, 57-63. [CrossRef]

19. Heinzer, R.; Gaudreau, H.; Décary, A.; Sforza, E.; Petit, D.; Morisson, F.; Montplaisir, J. Slow-Wave Activity in Sleep Apnea Patients Before and After Continuous Positive Airway Pressure Treatment: Contribution to Daytime Sleepiness. Chest 2001, 119, 1807-1813. [CrossRef]

20. Carvalho, D.Z.; Gerhardt, G.J.L.; Dellagustin, G.; de Santa-Helena, E.L.; Lemke, N.; Segal, A.Z.; Schönwald, S.V. Loss of sleep spindle frequency deceleration in Obstructive Sleep Apnea. Clin. Neurophysiol. 2014, 125, 306-312. [CrossRef] [PubMed]

21. Ju, Y.E.S.; Zangrilli, M.A.; Finn, M.B.; Fagan, A.M.; Holtzman, D.M. Obstructive sleep apnea treatment, slow wave activity, and amyloid- $\beta$. Annals of neurology. Physiol. Behav. 2019, 85, 291-295. [CrossRef]

22. Peregrim, I.; Grešová, S.; Štimmelová, J.; Bačová, I.; Fulton, B.L.; Tokárová, D.; Gáborová, M.; Brandeburová, A.; Doničová, V.; Rusnáková, S.; et al. Strong coincidence between slow wave sleep and low AHI is explainable by the high instability of slow wave sleep to obstructive apnea exposure. Physiol. Res. 2019, 68, 857-865. [CrossRef]

23. Ren, R.; Covassin, N.; Zhang, Y.; Lei, F.; Yang, L.; Zhou, J.; Tan, L.; Li, T.; Li, Y.; Shi, J.; et al. Interaction between Slow Wave Sleep and Obstructive Sleep Apnea in Prevalent Hypertension. Hypertension 2020, 516-523. [CrossRef] [PubMed]

24. Born, J.; Wilhelm, I. System Consolidation of Memory During Sleep. Psychol. Res. 2012, 76, 192-203. [CrossRef] [PubMed]

25. Cirelli, C. Sleep and Synaptic Changes. Curr. Opin. Neurobiol. 2013, 23, 841-846. [CrossRef] [PubMed]

26. Polsek, D.; Gildeh, N.; Cash, D.; Winsky-Sommerer, R.; Williams, S.C.R.; Turkheimer, F.; Leschziner, G.D.; Morrell, M.J.; Rosenzweig, I. Obstructive Sleep Apnoea and Alzheimer's Disease: In Search of Shared Pathomechanisms. Neurosci. Biobehav. Rev. 2018, 86, 142-149. [CrossRef]

27. Rosenzweig, I.; Glasser, M.; Polsek, D.; Leschziner, G.D.; Williams, S.C.R.; Morrell, M.J. Sleep Apnoea and the Brain: A Complex Relationship. Lancet Respir. Med. 2015, 3, 404-414. [CrossRef]

28. Baril, A.-A.; Gagnon, K.; Brayet, P.; Montplaisir, J.; Carrier, J.; Soucy, J.-P.; Lafond, C.; Blais, H.; D’Aragon, C.; Gagnon, J.-F.; et al. Obstructive sleep apnea during REM sleep and daytime cerebral functioning: A regional cerebral blood flow study using high-resolution SPECT. J. Cereb. Blood Flow Metab. 2020, 40, 1230-1241. [CrossRef]

29. Gabryelska, A.; Białasiewicz, P. Association between excessive daytime sleepiness, REM phenotype and severity of obstructive sleep apnea. Sci. Rep. 2020, 10,1-6. [CrossRef]

30. Gagnon, K.; Baril, A.-A.; Montplaisir, J.; Carrier, J.; De Beaumont, L.; D’Aragon, C.; Chami, S.; Pelleieux, S.; Poirier, J.; Gauthier, S.; et al. Disconnection Between Self-Reported and Objective Cognitive Impairment in Obstructive Sleep Apnea. J. Clin. Sleep Med. 2019, 15, 409-415. [CrossRef]

31. Baril, A.A.; Martineau-Dussault, M.È.; Sanchez, E.; André, C.; Thompson, C.; Legault, J.; Gosselin, N. Obstructive Sleep Apnea and the Brain: A Focus on Gray and White Matter Structure. Curr. Neurol. Neurosci. Rep. 2021, 21, 1-11. [CrossRef] 
32. Ju, Y.-E.S.; Finn, M.B.; Sutphen, C.L.; Herries, E.M.; Jerome, G.M.; Ladenson, J.H.; Crimmins, D.L.; Fagan, A.M.; Holtzman, D.M. Obstructive sleep apnea decreases central nervous system- derived proteins in the cerebrospinal fluid. Ann. Neurol. 2016, 80, 154-159. [CrossRef] [PubMed]

33. Yun, C.H.; Lee, H.Y.; Lee, S.K.; Kim, H.; Seo, H.S.; Bang, S.A.; Kim, S.E.; Greve, D.N.; Au, R.; Shin, C.; et al. Amyloid Burden in Obstructive Sleep Apnea. J. Alzheimer Dis. 2017, 59, 21-29. [CrossRef] [PubMed]

34. André, C.; Rehel, S.; Kuhn, E.; Landeau, B.; Moulinet, I.; Touron, E.; Ourry, V.; Le Du, G.; Mézenge, F.; Tomadesso, C.; et al. Association of Sleep-Disordered Breathing with Alzheimer Disease Biomarkers in Community-Dwelling Older Adults: A Secondary Analysis of a Randomized Clinical Trial. JAMA Neurol. 2020, 77, 716-724. [CrossRef]

35. Jackson, M.L.; Cavuoto, M.; Schembri, R.; Doré, V.; Villemagne, V.L.; Barnes, M.; O’Donoghue, F.J.; Rowe, C.C.; Robinson, S.R. Severe Obstructive Sleep Apnea Is Associated with Higher Brain Amyloid Burden: A Preliminary PET Imaging Study. J. Alzheimer Dis. 2020, 78, 611-617. [CrossRef]

36. Liguori, C.; Mercuri, N.B.; Izzi, F.; Romigi, A.; Cordella, A.; Sancesario, G.; Placidi, F. Obstructive sleep apnea is associated with early but possibly modifiable Alzheimer's disease biomarkers changes. Sleep 2017, 40. [CrossRef] [PubMed]

37. Liguori, C.; Maestri, M.; Spanetta, M.; Placidi, F.; Bonanni, E.; Mercuri, N.B.; Guarnieri, B. Sleep-disordered breathing and the risk of Alzheimer's disease. Sleep Med. Rev. 2021, 55, 101375. [CrossRef]

38. Bubu, O.M.; Pirraglia, E.; Andrade, A.G.; Sharma, R.A.; Gimenez-Badia, S.; Umasabor-Bubu, O.Q.; Hogan, M.M.; Shim, A.M.; Mukhtar, F.; Sharma, N.; et al. Obstructive sleep apnea and longitudinal Alzheimer's disease biomarker changes. Sleep 2019, 42, 1-13. [CrossRef] [PubMed]

39. Elias, A.; Cummins, T.; Tyrrell, R.; Lamb, F.; Dore, V.; Williams, R.; Rosenfeld, J.V.; Hopwood, M.; Villemagne, V.L.; Rowe, C.C. Risk of Alzheimer's Disease in Obstructive Sleep Apnea Syndrome: Amyloid- $\beta$ and Tau Imaging. J. Alzheimer Dis. 2018, 66, 733-741. [CrossRef] [PubMed]

40. Sharma, R.A.; Varga, A.W.; Bubu, O.M.; Pirraglia, E.; Kam, K.; Parekh, A.; Wohlleber, M.; Miller, M.D.; Andrade, A.; Lewis, C.; et al. Obstructive Sleep Apnea Severity Affects Amyloid Burden in Cognitively Normal Elderly. Am. J. Respir. Crit. Care Med. 2018, 197, 933-943. [CrossRef] [PubMed]

41. Spira, A.P.; Yager, C.; Brandt, J.; Smith, G.S.; Zhou, Y.; Mathur, A.; Kumar, A.; Brašić, J.R.; Wong, D.F.; Wu, M.N. Objectively measured sleep and $\beta$-amyloid burden in older adults: A pilot study. SAGE Open Med. 2014, 2, 205031211454652. [CrossRef]

42. Osorio, R.S.; Ayappa, I.; Mantua, J.; Gumb, T.; Varga, A.; Mooney, A.M.; Burschtin, O.E.; Taxin, Z.; During, E.; Spector, N.; et al. The interaction between sleep-disordered breathing and apolipoprotein E genotype on cerebrospinal fluid biomarkers for Alzheimer's disease in cognitively normal elderly individuals. Neurobiol. Aging 2014, 35, 1318-1324. [CrossRef]

43. Motamedi, V.; Kanefsky, R.; Matsangas, P.; Mithani, S.; Jeromin, A.; Brock, M.S.; Mysliwiec, V.; Gill, J. Elevated tau and interleukin-6 concentrations in adults with obstructive sleep apnea. Sleep Med. 2018, 43, 71-76. [CrossRef] [PubMed]

44. Kinney, J.W.; Bemiller, S.M.; Murtishaw, A.S.; Leisgang, A.M.; Salazar, A.M.; Lamb, B.T. Inflammation as a Central Mechanism in Alzheimer's Disease. Alzheimer Dement. Transl. Res. Clin. Interv. 2018, 4, 575-590. [CrossRef] [PubMed]

45. Blackwell, T.; Yaffe, K.; Ancoli-Israel, S.; Redline, S.; Ensrud, K.E.; Stefanick, M.L.; Laffan, A.; Stone, K.L. Associations Between Sleep Architecture and Sleep-Disordered Breathing and Cognition in Older Community-Dwelling Men: The Osteoporotic Fractures in Men Sleep Study. J. Am. Geriatr. Soc. 2011, 59, 2217-2225. [CrossRef] [PubMed]

46. Boland, L.L.; Shahar, E.; Iber, C.; Knopman, D.S.; Kuo, T.F.; Javier Nieto, F. Measures of Cognitive Function in Persons with Varying Degrees of Sleep-Disordered Breathing: The Sleep Heart Health Study. J. Sleep Res. 2002, 11, 265-272. [CrossRef] [PubMed]

47. Cosentino, F.I.I.; Bosco, P.; Drago, V.; Prestianni, G.; Lanuzza, B.; Iero, I.; Tripodi, M.; Spada, R.S.; Toscano, G.; Caraci, F.; et al. The $\mathrm{APOE} \varepsilon 4$ Allele Increases the Risk of Impaired Spatial Working Memory in Obstructive Sleep Apnea. Sleep Med. 2008, 9, 831-839. [CrossRef] [PubMed]

48. Dlugaj, M.; Weinreich, G.; Weimar, C.; Stang, A.; Dragano, N.; Wessendorf, T.E.; Teschler, H.; Winkler, A.; Wege, N.; Moebus, S.; et al. Sleep-Disordered Breathing, Sleep Quality, and Mild Cognitive Impairment in the General Population. J. Alzheimer Dis. 2014, 41, 479-497. [CrossRef]

49. Foley, D.J.; Masaki, K.; White, L.; Larkin, E.K.; Monjan, A.; Redline, S. Sleep-Disordered Breathing and Cognitive Impairment in Elderly Japanese-American Men. Sleep 2003, 26, 596-599. [CrossRef] [PubMed]

50. Haba-Rubio, J.; Marti-Soler, H.; Tobback, N.; Andries, D.; Marques-Vidal, P.; Waeber, G.; Vollenweider, P.; Von Gunten, A.; Preisig, M.; Castelao, E.; et al. Sleep Characteristics and Cognitive Impairment in the General Population: The HypnoLaus study. Neurology 2017, 88, 463-469. [CrossRef]

51. Sforza, E.; Roche, F.; Thomas-Anterion, C.; Kerleroux, J.; Beauchet, O.; Celle, S.; Maudoux, D.; Pichot, V.; Laurent, B.; Barthélémy, J.C. Cognitive Function and Sleep Related Breathing Disorders in a Healthy Elderly Population: The Synapse Study. Sleep 2010, 33, 515-521. [CrossRef]

52. Spira, A.P.; Blackwell, T.; Stone, K.L.; Redline, S.; Cauley, J.A.; Ancoli-Israel, S.; Yaffe, K. Sleep-Disordered Breathing and Cognition in Older Women. J. Am. Geriatr. Soc. 2008, 56, 45-50. [CrossRef] [PubMed]

53. Dealberto, M.-J.; Pajot, N.; Courbon, D.; Alpérovitch, A. Breathing Disorders During Sleep and Cognitive Performance in an Older Community Sample: The EVA Study. J. Am. Geriatr. Soc. 1996, 44, 1287-1294. [CrossRef] 
54. Quan, S.F.; Wright, R.; Baldwin, C.M.; Kaemingk, K.L.; Goodwin, J.L.; Kuo, T.F.; Kaszniak, A.; Boland, L.L.; Caccappolo, E.; Bootzin, R.R. Obstructive Sleep Apnea-Hypopnea and Neurocognitive Functioning in the Sleep Heart Health Study. Sleep Med. 2006, 7, 498-507. [CrossRef]

55. Ding, X.; Kryscio, R.J.; Turner, J.; Jicha, G.A.; Cooper, G.; Caban-Holt, A.; Schmitt, F.A.; Abner, E.L. Self-Reported Sleep Apnea and Dementia Risk: Findings from the Prevention of Alzheimer's Disease with Vitamin E and Selenium Trial. J. Am. Geriatr. Soc. 2016, 64, 2472-2478. [CrossRef] [PubMed]

56. Lutsey, P.L.; Bengtson, L.G.S.; Punjabi, N.M.; Shahar, E.; Mosley, T.H.; Gottesman, R.F.; Wruck, L.M.; MacLehose, R.F.; Alonso, A. Obstructive Sleep Apnea and 15-Year Cognitive Decline: The Atherosclerosis Risk in Communities (ARIC) Study. Sleep 2016, 39, 309-316. [CrossRef] [PubMed]

57. Lutsey, P.L.; Misialek, J.R.; Mosley, T.H.; Gottesman, R.F.; Punjabi, N.M.; Shahar, E.; MacLehose, R.; Ogilvie, R.P.; Knopman, D.; Alonso, A. Sleep Characteristics and Risk of Dementia and Alzheimer's Disease: The Atherosclerosis Risk in Communities Study. Alzheimer Dement. 2018, 14, 157-166. [CrossRef] [PubMed]

58. Saint Martin, M.; Sforza, E.; Roche, F.; Barthélémy, J.C.; Thomas-Anterion, C. Sleep Breathing Disorders and Cognitive Function in the Elderly: An 8-Year Follow-up Study. The Proof-Synapse Cohort. Sleep 2015, 38, 179-187. [CrossRef]

59. Yaffe, K.; Laffan, A.M.; Harrison, S.L.; Redline, S.; Spira, A.P.; Ensrud, K.E.; Ancoli-Israel, S.; Stone, K.L. Sleep-disordered breathing, hypoxia, and risk of mild cognitive impairment and dementia in older women. J. Am. Med. Assoc. 2011, 306, 613-619. [CrossRef]

60. Bubu, O.M.; Andrade, A.G.; Umasabor-Bubu, O.Q.; Hogan, M.M.; Turner, A.D.; de Leon, M.J.; Ogedegbe, G.; Ayappa, I.; JeanLouis, G.; Jackson, M.L.; et al. Obstructive Sleep Apnea, Cognition and Alzheimer's Disease: A Systematic Review Integrating Three Decades of Multidisciplinary Research. Sleep Med. Rev. 2020, 50, 101250. [CrossRef]

61. Bucks, R.S.; Olaithe, M.; Eastwood, P. Neurocognitive Function in Obstructive Sleep Apnoea: A Meta-Review. Respirology 2013, 18, 61-70. [CrossRef]

62. Olaithe, M.; Bucks, R.S.; Hillman, D.R.; Eastwood, P.R. Cognitive Deficits in Obstructive Sleep Apnea: Insights from a MetaReview and Comparison with Deficits Observed in COPD, Insomnia, and Sleep Deprivation. Sleep Med. Rev. 2018, 38 , 39-49. [CrossRef]

63. Emamian, F.; Khazaie, H.; Tahmasian, M.; Leschziner, G.D.; Morrell, M.J.; Hsiung, G.Y.R.; Rosenzweig, I.; Sepehry, A.A. The Association Between Obstructive Sleep Apnea and Alzheimer's Disease: A Meta-Analysis Perspective. Front. Aging Neurosci. 2016, 8, 1-8. [CrossRef] [PubMed]

64. Zhu, X.; Zhao, Y. Sleep-disordered breathing and the risk of cognitive decline: A meta-analysis of 19,940 participants. Sleep Breath 2018, 22, 165-173. [CrossRef] [PubMed]

65. Shi, L.; Chen, S.J.; Ma, M.Y.; Bao, Y.P.; Han, Y.; Wang, Y.M.; Shi, J.; Vitiello, M.V.; Lu, L. Sleep disturbances increase the risk of dementia: A systematic review and meta-analysis. Sleep Med. Rev. 2018, 40, 4-16. [CrossRef]

66. Kim, S.J.; Lee, J.H.; Lee, D.Y.; Jhoo, J.H.; Woo, J.I. Neurocognitive dysfunction associated with sleep quality and sleep apnea in patients with mild cognitive impairment. Am. J. Geriatr. Psychiatry 2011, 19, 374-381. [CrossRef] [PubMed]

67. Terpening, Z.; Lewis, S.J.; Yee, B.; Grunstein, R.; Hickie, I.B.; Naismith, S.L. Association between sleep-disordered breathing and neuropsychological performance in older Adults with mild cognitive impairment. J. Alzheimer Dis. 2015, 46, 157-165. [CrossRef]

68. Cross, N.; Lampit, A.; Pye, J.; Grunstein, R.R.; Marshall, N.; Naismith, S.L. Is Obstructive Sleep Apnoea Related to Neuropsychological Function in Healthy Older Adults? A Systematic Review and Meta-Analysis. Neuropsychol. Rev. 2017, $27,389-402$. [CrossRef]

69. Ramos, A.R.; Tarraf, W.; Rundek, T.; Redline, S.; Wohlgemuth, W.K.; Loredo, J.S.; Sacco, R.L.; Lee, D.J.; Arens, R.; Lazalde, P.; et al. Obstructive Sleep Apnea and Neurocognitive Function in a Hispanic/Latino Population. Neurology 2015, 84, 391-398. [CrossRef]

70. Bade, B.C.; Strange, C.; Lal, C. Effect of obstructive sleep apnea treatment on mail-in cognitive function screening instrument. Am. J. Med. Sci. 2014, 348, 215-218. [CrossRef]

71. Chang, W.P.; Liu, M.E.; Chang, W.C.; Yang, A.C.; Ku, Y.C.; Pai, J.T.; Huang, H.L.; Tsai, S.J. Sleep Apnea and the Risk of Dementia: A Population-Based 5-Year Follow-Up Study in Taiwan. PLoS ONE 2013, 8, e078655. [CrossRef]

72. Nikodemova, M.; Finn, L.; Mignot, E.; Salzieder, N.; Peppard, P.E. Association of Sleep Disordered Breathing and Cognitive Deficit in APOE $\varepsilon 4$ Carriers. Sleep 2013, 36, 873-880. [CrossRef]

73. O'Hara, R.; Schröder, C.M.; Kraemer, H.C.; Kryla, N.; Cao, C.; Miller, E.; Schatzberg, A.F.; Yesavage, J.A.; Murphy, G.M. Nocturnal sleep apnea/hypopnea is associated with lower memory performance in APOE $\varepsilon 4$ carriers. Neurology 2005, 65, 642-644. [CrossRef]

74. Lal, C.; DiBartolo, M.M.; Kumbhare, S.; Strange, C.; Joseph, J.E. Impact of obstructive sleep apnea syndrome on cognition in early postmenopausal women. Sleep Breath. 2016, 20, 621-626. [CrossRef] [PubMed]

75. Lin, Y.N.; Zhou, L.N.; Zhang, X.J.; Li, Q.Y.; Wang, Q.; Xu, H.J. Combined Effect of Obstructive Sleep Apnea and Chronic Smoking on Cognitive Impairment. Sleep Breath. 2016, 20, 51-59. [CrossRef] [PubMed]

76. Alchanatis, M.; Zias, N.; Deligiorgis, N.; Amfilochiou, A.; Dionellis, G.; Orphanidou, D. Sleep Apnea-Related Cognitive Deficits and Intelligence: An Implication of Cognitive Reserve Theory. J. Sleep Res. 2005, 14, 69-75. [CrossRef] [PubMed]

77. Shen, Y.C.; Kung, S.C.; Chang, E.T.; Hong, Y.L.; Wang, L.Y. The impact of obesity in cognitive and memory dysfunction in obstructive sleep apnea syndrome. Int. J. Obes. 2019, 43, 355-361. [CrossRef] [PubMed]

78. Mansukhani, M.P.; Kolla, B.P.; Somers, V.K. Hypertension and Cognitive Decline: Implications of Obstructive Sleep Apnea. Front. Cardiovasc. Med. 2019, 6, 1-9. [CrossRef] 
79. Kato, K.; Noda, A.; Yasuma, F.; Matsubara, Y.; Miyata, S.; Iwamoto, K.; Miyazaki, S.; Ozaki, N. Effects of sleep-disordered breathing and hypertension on cognitive function in elderly adults. Clin. Exp. Hypertens. 2019, 42, 250-256. [CrossRef] [PubMed]

80. Kerner, N.A.; Roose, S.P. Obstructive Sleep Apnea is Linked to Depression and Cognitive Impairment: Evidence and Potential Mechanisms. Am. J. Geriatr. Psychiatry 2016, 24, 496-508. [CrossRef]

81. Mendelson, M.; Bailly, S.; Marillier, M.; Flore, P.; Borel, J.C.; Vivodtzev, I.; Doutreleau, S.; Verges, S.; Tamisier, R.; Pépin, J.-L. Obstructive Sleep apnea Syndrome, Objectively measured Physical activity and exercise training interventions: A Systematic Review and meta-analysis. Front. Neurol. 2018, 9. [CrossRef] [PubMed]

82. Zamarron, C.; Gude, F.; Otero, Y.; Alvarez, J.M.; Golpe, A.; Rodriguez, J.R. Prevalence of Sleep Disordered Breathing and Sleep Apnea in 50- to 70-Year-Old Individuals. Respiration 1999, 66, 317-322. [CrossRef] [PubMed]

83. Riedel, B.C.; Thompson, P.M.; Brinton, R.D. Age, APOE and sex: Triad of risk of Alzheimer's disease. J. Steroid Biochem. Mol. Biol. 2016, 160, 134-147. [CrossRef] [PubMed]

84. Eikermann, M.; Jordan, A.S.; Chamberlin, N.L.; Gautam, S.; Wellman, A.; Lo, Y.L.; White, D.P.; Malhotra, A. The Influence of Aging on Pharyngeal Collapsibility During Sleep. Chest 2007, 131, 1702-1709. [CrossRef]

85. Worsnop, C.; Kay, A.; Kim, Y.; Trinder, J.; Pierce, R. Effect of Age on Sleep Onset-Related Changes in Respiratory Pump and Upper Airway Muscle Function. J. Appl. Physiol. 2000, 88, 1831-1839. [CrossRef]

86. Prince, M.; Bryce, R.; Albanese, E.; Wimo, A.; Ribeiro, W.; Ferri, C.P. The global prevalence of dementia: A systematic review and metaanalysis. Alzheimer Dement. 2013, 9, 63-75. [CrossRef]

87. Nebel, R.A.; Aggarwal, N.T.; Barnes, L.L.; Gallagher, A.; Goldstein, J.M.; Kantarci, K.; Mallampalli, M.P.; Mormino, E.C.; Scott, L.; $\mathrm{Yu}$, W.H.; et al. Understanding the impact of sex and gender in Alzheimer's disease: A call to action. Alzheimer Dement. 2018, 14, 1171-1183. [CrossRef] [PubMed]

88. Appleton, S.L.; Gill, T.K.; Lang, C.J.; Taylor, A.W.; McEvoy, R.D.; Stocks, N.P.; González-Chica, D.A.; Adams, R.J. Prevalence and Comorbidity of Sleep Conditions in Australian Adults: 2016 Sleep Health Foundation National Survey. Sleep Heal. 2018, 4, 13-19. [CrossRef] [PubMed]

89. Hiestand, D.M.; Britz, P.; Goldman, M.; Phillips, B. Prevalence of symptoms and risk of sleep apnea in the US population. Chest 2006, 130, 780-786. [CrossRef]

90. Huang, T.; Lin, B.M.; Markt, S.C.; Stampfer, M.J.; Laden, F.; Hu, F.B.; Tworoger, S.S.; Redline, S. Sex Differences in the Associations of Obstructive Sleep Apnoea with Epidemiological Factors. Eur. Respir. J. 2018, 51, 1-10. [CrossRef]

91. Peppard, P.E.; Young, T.; Barnet, J.H.; Palta, M.; Hagen, E.W.; Hla, K.M. Increased Prevalence of Sleep-Disordered Breathing in Adults. Am. J. Epidemiol. 2013, 177, 1006-1014. [CrossRef]

92. Sunwoo, J.S.; Hwangbo, Y.; Kim, W.J.; Chu, M.K.; Yun, C.H.; Yang, K.I. Prevalence, sleep characteristics, and comorbidities in a population at high risk for obstructive sleep apnea: A nationwide questionnaire study in South Korea. PLoS ONE 2018, 13, e0193549. [CrossRef]

93. Matsumoto, T.; Murase, K.; Tabara, Y.; Minami, T.; Kanai, O.; Takeyama, H.; Takahashi, N.; Hamada, S.; Tanizawa, K.; Wakamura, T.; et al. Sleep disordered breathing and metabolic comorbidities across sex and menopausal status in East Asians: The Nagahama Study. Eur. Respir. J. 2020, 56. [CrossRef]

94. Bonsignore, M.R.; Saaresranta, T.; Riha, R.L.; Riha, R.; Bonsignore, M. Sex Differences in Obstructive Sleep Apnoea. Eur. Respir. Rev. 2019, 28, 1-11. [CrossRef]

95. Lozo, T.; Komnenov, D.; Badr, M.S.; Mateika, J.H. Sex Differences in Sleep Disordered Breathing in Adults. Respir. Physiol. Neurobiol. 2017, 245, 65-75. [CrossRef] [PubMed]

96. Chiu, H.-Y.; Lai, F.-C.; Chen, P.-Y.; Tsai, P.-S. Differences Between Men and Women Aged 65 and Older in the Relationship Between Self-Reported Sleep and Cognitive Impairment: A Nationwide Survey in Taiwan. Am. Geriatr. Soc. 2016, 64, 2051-2058. [CrossRef] [PubMed]

97. Macey, P.M.; Kumar, R.; Yan-Go, F.L.; Woo, M.A.; Harper, R.M. Sex differences in white matter alterations accompanying obstructive sleep apnea. Sleep 2012, 35, 1603-1613. [CrossRef]

98. Macey, P.M.; Haris, N.; Kumar, R.; Thomas, M.A.; Woo, M.A.; Harper, R.M. Obstructive sleep apnea and cortical thickness in females and males. PLoS ONE 2018, 13, e0193854. [CrossRef]

99. Macey, P.M.; Prasad, J.P.; Ogren, J.A.; Moiyadi, A.S.; Aysola, R.S.; Kumar, R.; Yan-Go, F.L.; Woo, M.A.; Albert Thomas, M.; Harper, R.M. Sex-specific hippocampus volume changes in obstructive sleep apnea. Neuroimage Clin. 2018, 20, 305-317. [CrossRef]

100. Bouloukaki, I.; Mermigkis, C.; Tzanakis, N.; Kallergis, E.; Moniaki, V.; Mauroudi, E.; Schiza, S.E. Evaluation of Inflammatory Markers in a Large Sample of Obstructive Sleep Apnea Patients without Comorbidities. Mediat. Inflamm. 2017, 2017. [CrossRef]

101. Gouveris, H.; Bahr, K.; Jahn, C.; Matthias, C.; Simon, P. The Apnea-Hypopnea Index Underestimates Systemic Inflammation in Women with Sleep-Disordered Breathing. J. Women's Heal. 2018, 27, 920-926. [CrossRef]

102. Scheyer, O.; Rahman, A.; Hristov, H.; Berkowitz, C.; Isaacson, R.S.; Diaz Brinton, R.; Mosconi, L. Female Sex and Alzheimer's Risk: The Menopause Connection. J. Prev. Alzheimer Dis. 2018, 5, 225-230. [CrossRef]

103. Mosconi, L.; Rahman, A.; Diaz, I.; Wu, X.; Scheyer, O.; Hristov, H.W.; Vallabhajosula, S.; Isaacson, R.S.; de Leon, M.J.; Brinton, R.D. Increased Alzheimer's risk during the menopause transition: A 3-year longitudinal brain imaging study. PLoS ONE 2018, 13, e0207885. [CrossRef] 
104. Heinzer, R.; Marti-Soler, H.; Marques-Vidal, P.; Tobback, N.; Andries, D.; Waeber, G.; Preisig, M.; Vollenweider, P.; Haba-Rubio, J. Impact of Sex and Menopausal Status on the Prevalence, Clinical Presentation, and Comorbidities of Sleep-Disordered Breathing. Sleep Med. 2018, 51, 29-36. [CrossRef]

105. Bixler, E.O.; Vgontzas, A.N.; Lin, H.-M.; Ten Have, T.; Rein, J.; Vela-Bueno, A.; Kales, A. Prevalence of Sleep-disordered Breathing in Women: Effects of Gender. Am. J. Respir. Crit. Care Med. 2001, 163, 608-613. [CrossRef]

106. Netzer, N.C.; Stoohs, R.A.; Netzer, C.M.; Clark, K.; Strohl, K.P. Using the Berlin Questionnaire to Identify Patients at Risk for the Sleep Apnea Syndrome. Ann. Intern. Med. 1999, 131, 485-491. [CrossRef]

107. Gervais, N.J.; Mong, J.A.; Lacreuse, A. Ovarian hormones, sleep and cognition across the adult female lifespan: An integrated perspective. Front. Neuroendocr. 2017, 47, 134-153. [CrossRef]

108. Zhou, C.C.; Wu, Q.; Wang, Z.; Wang, Q.; Liang, Y.; Liu, S. The Effect of Hormone Replacement Therapy on Cognitive Function in Female Patients With Alzheimer's Disease: A Meta-Analysis. Am. J. Alzheimers. Dis. Other Demen. 2020, 35, 1-7. [CrossRef]

109. Whitmer, R.A.; Gustafson, D.R.; Barrett-Connor, E.; Haan, M.N.; Gunderson, E.P.; Yaffe, K. Central Obesity and Increased Risk of Dementia more than Three Decades Later. Neurology 2008, 71, 1057-1064. [CrossRef]

110. Miller, A.A.; Spencer, S.J. Obesity and Neuroinflammation: A Pathway to Cognitive Impairment. Brain. Behav. Immun. 2014, 42, 10-21. [CrossRef]

111. Barnham, K.J.; Masters, C.L.; Bush, A.I. Neurodegenerative Diseases and Oxidative Stress. Nat. Rev. Drug Discov. 2004, 3, 205-214. [CrossRef]

112. Young, T.; Skatrud, J.; Peppard, P.E. Risk Factors for Obstructive Sleep Apnea in Adults. J. Am. Med. Assoc. 2004, 291, 2013-2016. [CrossRef] [PubMed]

113. Carter, R.; Watenpaugh, D.E. Obesity and Obstructive Sleep Apnea: Or is it OSA and Obesity? Pathophysiology 2008, 15, 71-77. [CrossRef]

114. Chatterjee, S.; Peters, S.A.E.; Woodward, M.; Arango, S.M.; Batty, G.D.; Beckett, N.; Beiser, A.; Borenstein, A.R.; Crane, P.K.; Haan, M.; et al. Type 2 diabetes as a risk factor for dementia in women compared with men: A pooled analysis of 2.3 million people comprising more than 100,000 cases of dementia. Diabetes Care 2016, 39, 300-307. [CrossRef]

115. Rad, S.K.; Arya, A.; Karimian, H.; Madhavan, P.; Rizwan, F.; Koshy, S.; Prabhu, G. Mechanism involved in insulin resistance via accumulation of $\beta$-amyloid and neurofibrillary tangles: Link between type 2 diabetes and Alzheimer's disease. Drug Des. Devel. 2018, 12, 3999-4021. [CrossRef]

116. Stanciu, G.D.; Bild, V.; Ababei, D.C.; Rusu, R.N.; Cobzaru, A.; Paduraru, L.; Bulea, D. Link between Diabetes and Alzheimer's Disease Due to the Shared Amyloid Aggregation and Deposition Involving Both Neurodegenerative Changes and Neurovascular Damages. J. Clin. Med. 2020, 9, 1713. [CrossRef]

117. Biessels, G.J.; Despa, F. Cognitive decline and dementia in diabetes mellitus: Mechanisms and clinical implications. Nat. Rev. Endocrinol. 2018, 14, 591-604. [CrossRef] [PubMed]

118. Meslier, N.; Gagnadoux, F.; Giraud, P.; Person, C.; Ouksel, H.; Urban, T.; Racineux, J.-L. Impaired Glucose-Insulin Metabolism in Males with Obstructive Sleep Apnoea Syndrome. Eur. Respir. J. 2003, 22, 156-160. [CrossRef]

119. Foster, G.D.; Sanders, M.H.; Millman, R.; Zammit, G.; Borradaile, K.E.; Newman, A.B.; Wadden, T.A.; Kelley, D.; Wing, R.R.; Sunyer, F.X.P.; et al. Obstructive Sleep Apnea Among Obese Patients With Type 2 Diabetes. Diabetes Care 2009, 32, 1017-1019. [CrossRef]

120. Reichmuth, K.J.; Austin, D.; Skatrud, J.B.; Young, T. Association of Sleep Apnea and Type II Diabetes: A Population-based Study. Am. J. Respir. Crit. Care Med. 2005, 172, 1590-1595. [CrossRef]

121. Holingue, C.; Wennberg, A.; Berger, S.; Polotsky, V.Y.; Spira, A.P. Disturbed Sleep and Diabetes: A Potential Nexus of Dementia Risk. Metabolism 2018, 84, 85-93. [CrossRef]

122. Jehan, S.; Myers, A.K.; Zizi, F.; Pandi-Perumal, S.R.; Jean-Louis, G.; McFarlane, S.I. Obesity, Obstructive Sleep Apnea and Type 2 Diabetes Mellitus: Epidemiology and Pathophysiologic Insights. Sleep Med. Disord. Int. J. 2018, 2, 52-58.

123. Lurie, A. Metabolic Disorders Associated with Obstructive Sleep Apnea in Adults. In Obstructive Sleep Apnea in Adults; Karger Publishers: Berlin, Germany, 2011; pp. 67-138.

124. Saetung, S.; Nimitphong, H.; Siwasaranond, N.; Sumritsopak, R.; Jindahra, P.; Krairit, O.; Thakkinstian, A.; Anothaisintawee, T.; Reutrakul, S. The Relationship Between Sleep and Cognitive Function in Patients with Prediabetes and Type 2 Diabetes. Acta Diabetol. 2018, 55, 917-925. [CrossRef]

125. McGrath, E.R.; Beiser, A.S.; DeCarli, C.; Plourde, K.L.; Vasan, R.S.; Greenberg, S.M.; Seshadri, S. Blood pressure from mid- to late life and risk of incident dementia. Neurology 2017, 89, 2447-2454. [CrossRef]

126. Konecny, T.; Kara, T.; Somers, V.K. Obstructive sleep apnea and hypertension: An update. Hypertension 2014, 63, 203-209. [CrossRef]

127. Hou, H.; Zhao, Y.; Yu, W.; Dong, H.; Xue, X.; Ding, J.; Xing, W.; Wang, W. Association of obstructive sleep apnea with hypertension: A systematic review and meta-analysis. J. Glob. Health 2018, 8, 1-10. [CrossRef] [PubMed]

128. Abboud, F.; Kumar, R. Obstructive sleep apnea and insight into mechanisms of sympathetic overactivity. J. Clin. Investig. 2014, 124, 1454-1457. [CrossRef] [PubMed]

129. Qiu, C.; Fratiglioni, L. A major role for cardiovascular burden in age-related cognitive decline. Nat. Rev. Cardiol. 2015, 12, 267-277. [CrossRef] 
130. Karlsson, I.K.; Ploner, A.; Song, C.; Gatz, M.; Pedersen, N.L.; Hägg, S. Genetic susceptibility to cardiovascular disease and risk of dementia. Transl. Psychiatry 2017, 7, e1142. [CrossRef]

131. McNicholas, W.T.; Bonsignore, M.R. The Management Committee of EU COST ACTION B26 Sleep Apnoea as an Independent Risk for Cardiovascular Disease: Current Evidence, Basic Mechanisms and Research Priorities. Eur. Respir. J. 2007, 29 , 156-178. [CrossRef]

132. Peppard, P.E.; Young, T.; Palta, M.; Skatrud, J. Prospective Study of the Association between Sleep-Disordered Breathing and Hypertension. N. Engl. J. Med. 2000, 342, 1378-1384. [CrossRef]

133. Lévy, P.; Pépin, J.L.; Arnaud, C.; Tamisier, R.; Borel, J.C.; Dematteis, M.; Godin-Ribuot, D.; Ribuot, C. Intermittent Hypoxia and Sleep-Disordered Breathing: Current Concepts and Perspectives. Eur. Respir. J. 2008, 32, 1082-1095. [CrossRef] [PubMed]

134. Ryan, S.; Taylor, C.T.; McNicholas, W.T. Selective Activation of Inflammatory Pathways by Intermittent Hypoxia in Obstructive Sleep Apnea Syndrome. Circulation 2005, 112, 2660-2667. [CrossRef] [PubMed]

135. Baumgart, M.; Snyder, H.M.; Carrillo, M.C.; Fazio, S.; Kim, H.; Johns, H. Summary of the Evidence on Modifiable Risk Factors for Cognitive Decline and Dementia: A Population-Based Perspective. Alzheimer Dement. 2015, 11, 718-726. [CrossRef] [PubMed]

136. Rusanen, M.; Kivipelto, M.; Quesenberry, C.P.; Zhou, J.; Whitmer, R.A. Heavy Smoking in Midlife and Long-Term Risk of Alzheimer Disease and Vascular Dementia. Arch. Intern. Med. 2011, 171, 333-339. [CrossRef]

137. Rehm, J.; Hasan, O.S.M.; Black, S.E.; Shield, K.D.; Schwarzinger, M. Alcohol use and dementia: A systematic scoping review. Alzheimer Res. 2019, 11,1-11. [CrossRef]

138. De La Monte, S.M.; Kril, J.J. Human alcohol-related neuropathology. Acta Neuropathol. 2014, 127, 71-90. [CrossRef]

139. Rehm, J.; Gmel Sr, G.E.; Gmel, G.; Hasan, O.S.M.; Imtiaz, S.; Popova, S.; Probst, C.; Roerecke, M.; Room, R.; Samokhvalov, A.V.; et al. The relationship between different dimensions of alcohol use and the burden of disease-An update. Addiction 2017, 112, 968-1001. [CrossRef]

140. Wiegmann, C.; Mick, I.; Brandl, E.J.; Heinz, A.; Gutwinski, S. Alcohol and dementia-What is the link? A systematic review. Neuropsychiatr. Dis. Treat. 2020, 16, 87-99. [CrossRef]

141. Peppard, P.E.; Austin, D.; Brown, R.L. Association of alcohol consumption and sleep disordered breathing in men and women. J. Clin. Sleep Med. 2007, 3, 265-270. [CrossRef]

142. Burgos-Sanchez, C.; Jones, N.N.; Avillion, M.; Gibson, S.J.; Patel, J.A.; Neighbors, J.; Zaghi, S.; Camacho, M. Impact of Alcohol Consumption on Snoring and Sleep Apnea: A Systematic Review and Meta-analysis. Otolaryngol. Neck Surg. 2020, 163, 1078-1086. [CrossRef]

143. Simou, E.; Britton, J.; Leonardi-Bee, J. Alcohol and the risk of sleep apnoea: A systematic review and meta-analysis. Sleep Med. 2018, 42, 38-46. [CrossRef] [PubMed]

144. Kolla, B.P.; Foroughi, M.; Saeidifard, F.; Chakravorty, S.; Wang, Z.; Mansukhani, M.P. The impact of alcohol on breathing parameters during sleep: A systematic review and meta-analysis. Sleep Med. Rev. 2018, 42, 59-67. [CrossRef]

145. Zotcheva, E.; Bergh, S.; Selbæk, G.; Krokstad, S.; Håberg, A.K.; Strand, B.H.; Ernstsen, L. Midlife physical activity, psychological distress, and dementia risk: The HUNT study. J. Alzheimer Dis. 2018, 66, 825-833. [CrossRef]

146. Edwards, C.; Almeida, O.P.; Ford, A.H. Obstructive sleep apnea and depression: A systematic review and meta-analysis. Maturitas 2020, 142, 45-54. [CrossRef]

147. Chen, Y.-H.; Keller, J.K.; Kang, J.-H.; Hsieh, H.-J.; Lin, H.-C. Obstructive Sleep Apnea and the Subsequent Risk of Depressive Disorder: A Population-Based Follow-up Study. J. Clin. Sleep Med. 2013, 9, 417-423. [CrossRef]

148. Peppard, P.E.; Szklo-Coxe, M.; Hla, K.M.; Young, T. Longitudinal Association of Sleep-Related Breathing Disorder and Depression. Arch. Intern. Med. 2006, 166, 1709-1715. [CrossRef]

149. Sforza, E.; De Saint Hilaire, Z.; Pelissolo, A.; Rochat, T.; Ibanez, V. Personality, anxiety and mood traits in patients with sleep-related breathing disorders: Effect of reduced daytime alertness. Sleep Med. 2002, 3, 139-145. [CrossRef]

150. Power, M.C.; Adar, S.D.; Yanosky, J.D.; Weuve, J. Exposure to air pollution as a potential contributor to cognitive function, cognitive decline, brain imaging, and dementia: A systematic review of epidemiologic research. Neurotoxicology 2016, 56, 235-253. [CrossRef]

151. Peters, R.; Ee, N.; Peters, J.; Booth, A.; Mudway, I.; Anstey, K.J. Air Pollution and Dementia: A Systematic Review. J. Alzheimer Dis. 2019, 70, S145-S163. [CrossRef]

152. Clark, D.P.Q.; Son, D.B.; Bowatte, G.; Senaratna, C.V.; Lodge, C.; Perret, J.L.; Hamilton, G.S.; Dharmage, S. The association between traffic-related air pollution and obstructive sleep apnea: A systematic review. Sleep Med. Rev. 2020, 54, 101360. [CrossRef]

153. Laratta, C.R.; Kendzerska, T.; Carlsten, C.; Brauer, M.; van Eeden, S.F.; Allen, A.J.M.H.; Fox, N.; Peres, B.U.; Ayas, N.T. Air Pollution and Systemic Inflammation in Patients With Suspected OSA Living in an Urban Residential Area. Chest 2020, 158, 1713-1722. [CrossRef]

154. Paul, K.C.; Haan, M.; Yu, Y.; Inoue, K.; Mayeda, E.R.; Dang, K.; Wu, J.; Jerrett, M.; Ritz, B. Traffic-Related Air Pollution and Incident Dementia: Direct and Indirect Pathways Through Metabolic Dysfunction. J. Alzheimer Dis. 2020, 76, 1477-1491. [CrossRef]

155. Yu, Y.; Haan, M.; Paul, K.C.; Mayeda, E.R.; Jerrett, M.; Wu, J.; Lee, E.; Su, J.; Shih, I.-F.; Inoue, K.; et al. Metabolic dysfunction modifies the influence of traffic-related air pollution and noise exposure on late-life dementia and cognitive impairment. Environ. Epidemiol. 2020, 4, e122. [CrossRef] [PubMed]

156. Poirier, J.; Davignon, J.; Bouthillier, D.; Kogan, S.; Bertrand, P.; Gauthier, S. Apolipoprotein E polymorphism and Alzheimer's disease. Lancet 1993, 342, 697-699. [CrossRef] 
157. Strittmatter, W.J.; Saunders, A.M.; Schmechel, D.; Pericak-Vance, M.; Enghild, J.; Salvesen, G.S.; Roses, A.D. Apolipoprotein E: High-avidity binding to $\beta$-amyloid and increased frequency of type 4 allele in late-onset familial Alzheimer disease. Proc. Natl. Acad. Sci. USA 1993, 90, 1977-1981. [CrossRef]

158. Leduc, V.; Jasmin-Bélanger, S.; Poirier, J. APOE and cholesterol homeostasis in Alzheimer's disease. Trends Mol. Med. 2010, 16, 469-477. [CrossRef]

159. Kim, J.; Basak, J.M.; Holtzman, D.M. The Role of Apolipoprotein E in Alzheimer's Disease. Neuron 2009, 63, 287-303. [CrossRef]

160. Bondi, M.W.; Salmon, D.P.; Monsch, A.U.; Galasko, D.; Butters, N.; Klauber, M.R.; Thal, L.J.; Saitoh, T. Episodic memory changes are associated with the APOE-4 allele in nondemented older adults. Neurology 1995, 45, 2203-2206. [CrossRef]

161. Helkala, E.-L.; Koivisto, K.; Hänninen, T.; Matti, V.; Kervinen, K.; Kuusisto, J.; Mykkänen, L.; Kesäniemi, Y.A.; Laakso, M.; Riekkinen, P. The association of apolipoprotein E polymorphism with memory: A population based study. Neurosci. Lett. 1995, 191, 141-144. [CrossRef]

162. O'Hara, R.; Yesavage, J.A.; Kraemer, H.C.; Mauricio, M.; Friedman, L.F.; Murphy, G.M.J. The APOE $€ 4$ allele Is Associated with Decline on Delayed Recall Performance in Community-Dwelling Older Adults. J. Am. Geriatr. Soc. 1998, 46, 1493-1498. [CrossRef]

163. Oviedo, D.C.; Lezcano, H.; Perez, A.R.; Villarreal, A.E.; Carreira, M.B.; Isaza, B.; Wesley, L.; Grajales, S.A.; Fernandez, S.; Frank, A.; et al. Vascular biomarkers and ApoE4 expression in mild cognitive impairment and Alzheimer's disease. Aims Neurosci. 2018, 5, 148-161. [CrossRef] [PubMed]

164. Kadotani, H.; Young, T.; Peppard, P.E.; Finn, L.; Colrain, I.M.; Murphy, G.M.; Page, P. Association Between Apolipoprotein E4 and Sleep-Disordered Breathing in Adults. J. Am. Med. Assoc. 2001, 285, 2888-2890. [CrossRef] [PubMed]

165. Foley, D.J.; Masaki, K.; White, L.; Redline, S.; Mignot, E.; Murphy, G.M.; Young, T. Relationship between apolipoprotein E $\varepsilon 4$ and sleep-disordered breathing at different ages. J. Am. Med. Assoc. 2001, 286, 1447-1448. [CrossRef]

166. Saarelainen, S.; Lehtimäki, T.; Kallonen, E.; Laasonen, K.; Poussa, T.; Nieminen, M.M. No relation between apolipoprotein E alleles and obstructive sleep apnea. Clin. Genet. 2008, 53, 147-148. [CrossRef] [PubMed]

167. Thakre, T.P.; Mamtani, M.R.; Kulkarni, H. Lack of association of the apoe $\varepsilon 4$ allele with the risk of obstructive sleep apnea: Meta-analysis and meta-regression. Sleep 2009, 32, 1507-1511. [CrossRef] [PubMed]

168. Norton, S.; Matthews, F.E.; Barnes, D.E.; Yaffe, K.; Brayne, C. Potential for Primary Prevention of Alzheimer's Disease: An Analysis of Population-Based Data. Lancet Neurol. 2014, 13, 788-794. [CrossRef]

169. Hamer, M.; Chida, Y. Physical Activity and Risk of Neurodegenerative Disease: A Systematic Review of Prospective Evidence. Psychol. Med. 2008, 39, 3-11. [CrossRef]

170. Liang, K.Y.; Mintun, M.A.; Fagan, A.M.; Goate, A.M.; Bugg, J.M.; Holtzman, D.M.; Morris, J.C.; Head, D. Exercise and Alzheimer's Disease Biomarkers in Cognitively Normal Older Adults. Ann. Neurol. 2010, 68, 311-318. [CrossRef]

171. Kline, C.E.; Crowley, E.P.; Ewing, G.B.; Burch, J.B.; Blair, S.N.; Durstine, J.L.; Davis, J.M.; Youngstedt, S.D. The Effect of Exercise Training on Obstructive Sleep Apnea and Sleep Quality: A Randomized Controlled Trial. Sleep 2011, 34, 1631-1640. [CrossRef]

172. Stern, Y. What Is Cognitive Reserve? Theory and Research Application of the Reserve Concept. J. Int. Neuropsychol. Soc. 2002, 8, 448-460. [CrossRef] 